\title{
Motivation and benefits of digital games for the elderly: a systematic literature review
}

\author{
Túlio Teixeira Cota ${ }^{1}$ \\ Lucila Ishitani ${ }^{1}$
}

\begin{abstract}
Resumo: Diversos estudos apontam que a média etária da população mundial está aumentando. Em virtude disso, os idosos anseiam por recursos que sejam acessíveis e adequados para seu uso, levando-se em conta as limitações ocasionadas com o avanço da idade. A tecnologia, por ser uma área que se popularizou à época dos jovens e adultos mais jovens, apresenta diversos recursos e aplicações que carecem de adequação para melhorar a experiência do idoso. Uma dessas aplicações consiste nos jogos digitais, foco deste trabalho. Baseada nesse contexto, foi realizada uma revisão sistemática de literatura nas principais publicações científicas que abordam as motivações e os benefícios de jogos digitais para os idosos. Foi possível inferir que alguns fatores específicos podem influenciar a motivação dos idosos para jogar, como o uso de narrativas, a associação com jogos tradicionais e a baixa complexidade do jogo, além de ter sido identificado o jogo casual como a modalidade mais apreciada por esse público. Além disso, concluiu-se que o jogo digital pode se revelar como um importante aliado dos idosos no combate às limitações que surgem com o aumento da idade, servindo de apoio, por exemplo, no tratamento de doenças relacionadas a aspectos cognitivos, físicos e psicológicos.
\end{abstract}

Palavras-chave: Jogos digitais. Idosos. Motivação.

\begin{abstract}
Several studies indicate that the median age of the world's population has increased. As a result, the elderly look forward for resources that are accessible and appropriate for their use, taking into account age restrictions. As the technology is an area that became popular at the time of the current youth and young adults, it has several resources and applications that require adaptation to improve the elderly experience. One of these applications is the digital games, the focus of this work. Based on this context, we performed a systematic literature review of the main scientific publications which address the motivations for playing digital games and also the benefits of digital games for the elderly. We could infer that some specific factors may influence the motivation of the elderly to play, such as the use of narratives, the association with traditional games and the low complexity of the game, and we could also conclude that casual games are the most appreciated type of game of this audience. Furthermore, we also found out that digital games is as an important resource in the fight against the elderly restrictions due to aging, supporting, for example, the treatment of diseases related to cognitive, physical and psychological aspects.
\end{abstract}

Keywords: Digital games. Elderly. Motivation.

\footnotetext{
${ }^{1}$ Mestrado em Informática, PUC Minas, Rua Walter Ianni, 255 - São Gabriel - Belo Horizonte (MG) - Brasil.

\{tulio.cota@sga.pucminas.br, lucila@pucminas.br\}
}

http://dx.doi.org/10.5335/rbca.2015.4190

Revista Brasileira de Computação Aplicada (ISSN 2176-6649), Passo Fundo, v. 7, n. 1, p. 2-16, abr. 2015 


\section{Introduction}

Although there is no consensus on what age a person could be considered old, the World Health Organization considers elderly all adults aged 65 years or more in developed countries and aged 60 years or more in underdeveloped countries [1]. In this work we will use the term elderly as synonymous of senior and older adults.

Surveys indicate that the world population in general is aging. The institute The UN World Population Prospects estimated that in 2045, for the first time in history, the number of seniors will exceed the number of children and adolescents up to 15 years old [2]. This Institute (2008) has also published that in 2008, about $22 \%$ of the European population was over 60 years old. This research also showed that in 2050 this number will increase to approximately $34 \%$ [3].

This increasing in life expectancy is due to several advances made throughout human history, especially in social and health fields. As an example, one can cite the discovery and treatment of various diseases, the use of technology in medicine, in addition to the improvements in social conditions, such as basic sanitation.

When entering in the senile age, humans are inevitably affected by several difficulties. People in this age group often suffer from limitations that mainly affect motor, perceptual, cognitive and psychosocial skills. As a result, activities that require manual dexterity or memory, for example, become more difficult to perform [4].

Helping to combat the emergence and evolution of these limitations, digital games can be used as tools to encourage the elderly to exercise physically and mentally, delaying the occurrence of diseases and thus improving their quality of life [5].

Despite this favorable scenario, the digital games industry still develops few games for the elderly. That is because it is more profitable to sell digital games for teens and younger adults [41]. Nevertheless, statistics show that there is a growing adoption of digital games by them. In the United States, for example, the number of players over 50 years increased from $9 \%$ in 1999 to $26 \%$ in 2008 [2].

As a result, this paper has the main objective to present the results of a systematic literature review to identify the main works about the motivational factors and benefits of digital games for the elderly, in order to contribute to the development of adequate games for them.

This paper is organized as follow. Section 2 presents the applied method. Section 3 presents the results. Section 4 discusses the answers to the research questions proposed. And finally, Section 5 presents our conclusions.

\section{Method}

This study consisted of a systematic literature review (SLR) based on the method used by [6]. Through a detailed survey, we aimed to identify the main motivational factors that lead older people to play, as well as to infer the benefits that the use of games can bring to these people. The steps of the systematic literature review are detailed in the following sections.

\subsection{Research questions}

The research questions that conducted this study were:

- RQ1. What are the main factors that motivate the elderly to become interested in digital games?

Revista Brasileira de Computação Aplicada (ISSN 2176-6649), Passo Fundo, v. 7, n. 1, p. 2-16, abr. 2015 
- RQ2. Which genres of digital games the elderly considers most well suited for them?

- RQ3. Which are the main benefits for the elderly that plays digital games?

The RQ1 was made with the aim of identifying which elements may influence the acceptance or rejection of a game by the elderly. This analysis may contribute to the development of guidelines to be followed when designing a game to this audience. RQ2 aims to check in the literature which are the types of games more suited to older people, or that make them feel more pleasure and become more immersed when they play. Finally, RQ3 aims to identify the studies, particularly in the areas of medicine and psychology, about the benefits of playing games.

\subsection{Search process}

We carried out the search for relevant work between 4 and 17 March 2013 on the databases presented in Tab. 1. IEEE Xplore and ACM Digital Library have been selected because of their importance in the field of exact sciences, especially in the area of technology. The ScienceDirect and Web of Knowledge have been selected for being reputable and for presenting studies in multidisciplinary fields such as psychology and medicine. The proceedings of SBGames were also considered as this conference is the main source of publications related to digital games in Brazil.

Table 1: Selected sources

\begin{tabular}{ll}
\hline Source & Acronym \\
\hline IEEE Xplore & IEEE \\
ACM Digital Library & ACM \\
ScienceDirect & SD \\
Web of Knowledge & WK \\
Proceedings of the Brazilian Symposium of Games and Digital Entertainment & SBGames
\end{tabular}

Aside from SBGames - whose consultation was done manually - the initial procedure to select the papers was performed automatically, using search engines of each source. The search string was developed in order to deal with the three main issues exposed in the research questions: elderly, digital games and motivation.

The following code shows the basic form of the search string, especially highlighting the terms used. However, the search engines of the selected sources have different processes, so that it was necessary some adjustments in accordance with the rules of each search engine. It is noteworthy that despite being a game mode suitable for the elderly [9, 15], "exergames" was not a term explicitly considered in the search string because these games require consoles which are resources little acquired by the elderly. Only about $11 \%$ of people over the age of 65 have this devices. [42].

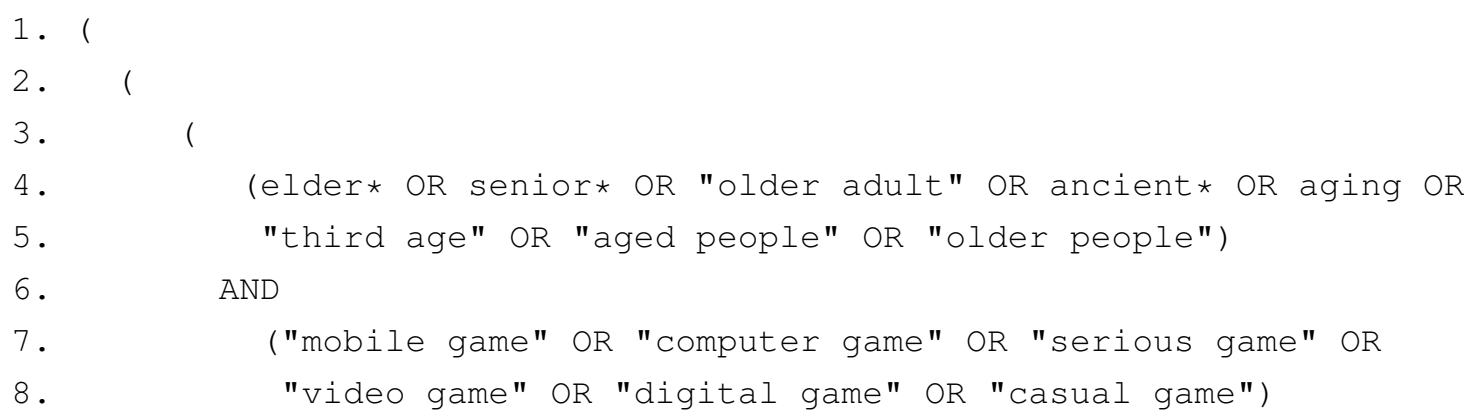




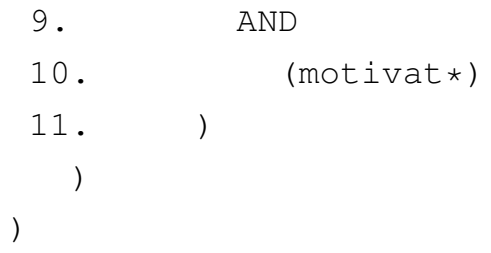

\subsection{Inclusion and exclusion criteria}

With the purpose of improving the quality of results returned by the initial search, the following criteria were used as filters for the inclusion of papers:

- Papers published from 2003 onwards, considering that the field of digital games has changed a lot over the last ten years and studies prior to this period could bring obsolete information.

- Papers with full text available and also with abstract for making easy the filtering process described in Section 2.4.

Similarly, we used the following criteria for the exclusion of papers from the final result:

- Studies that include games which are not digital.

- Studies which make available only their abstract.

- Studies available only as slideshows.

- Duplicate contents for the same study.

- Studies that have not been published by recognized bodies.

- Publications that were written in languages other than English and Portuguese.

- Publications of books, book chapters, reports, book reviews, bibliographies, editorials and not peer reviewed papers.

\subsection{Search filters}

After the initial search in the selected sources, a screening of the returned studies was manually performed, in order to find the ones that could help to answer the research questions raised. For this selection, we used the following filters:

- 1st filter: to read the title of each study returned in the initial search and verify their adherence to the subject of this work.

- 2nd filter: to read the abstract of each study selected in the 1 st filter and verify their adherence to the subject of this work.

- 3rd filter: to read the introduction and conclusion of each study selected in the 2nd filter and verify its adherence to the subject of this work. 


\subsection{Quality assessment}

After the selection of studies by the established filters, the papers were read and categorized, in order to provide an index of quality of the publication. For each selected work, the following questions were made:

- QA1. Do the used methods support the findings?

- QA2. Was the used methodology well detailed (methods, tools, procedures)?

- QA3. Is it possible to use or adapt the methodology in a new study to help answer a research question?

- QA4. Does the paper specifically (or predominantly) address the subject of digital games for the elderly?

- QA5. Does the paper present a consistent literature review, rich in content and references related to the subject of digital games for the elderly?

- QA6. Does the paper present conclusive results?

For each of these questions, it was assigned a score. A score of 0 was given to studies whose answer to the question of quality assessment was negative. Grade 5 was assigned to studies that partially answered the question, while the studies that provided adequate answers to a question were marked with the note 10 . The grades were set following the model used in the work of [6] and the scores may indicate to the reader what jobs are more closely related to the subject of this work.

\subsection{Data collection and analysis}

The following data were extracted from each study:

- Title and year of publication.

- Information related to the authors.

- Database consulted.

- Classification of the used methodology.

- Classification according to the research area.

- Summary and full text publication.

\subsection{Data analysis}

The data were tabulated so as to show:

- Title and year of publication.

- Authors.

- Used methodology classified as:

- systematic review of the literature (survey);

- case study;

- prototyping;

- qualitative research (observation, questionnaires, focus groups, interviews). 
- Classification regarding the research area:

- Computer science;

- Psychology;

- Education;

- Medicine.

- Contribution of the paper to answer each of the research questions.

- Score for each question of quality assessment.

\section{Results}

This section details the results at each performed step of the systematic literature review process.

\subsection{Search results}

Tab. 2 shows the results of the search performed. Despite being defined as an inclusion criteria that it would be considered the studies of the last 10 years, there were no publications of the years 2003 and 2004. In addition, two papers appeared more than once in the results. With the exclusion of these repetitions, it was possible to identify 37 studies that provide some contribution to answer the research questions.

Tab. 2 shows the overall results, which refer to all papers returned in the initial search; the relevant papers, which seemed to be suitable after application of the 2nd filter presented in Section 2.4; and selected papers after the application the 3rd filter presented in Section 2.4.

Table 2: Search results

\begin{tabular}{lcccccccccc}
\hline Source/Year & 2005 & 2006 & 2007 & 2008 & 2009 & 2010 & 2011 & 2012 & 2013 & Total \\
\hline ACM (Total) & 1 & 3 & 5 & 10 & 5 & 22 & 12 & 27 & 2 & 88 \\
ACM (Relevant) & 0 & 0 & 3 & 2 & 2 & 15 & 8 & 18 & 0 & 48 \\
ACM (Selected) & 0 & 0 & 1 & 2 & 0 & 7 & 5 & 11 & 0 & 26 \\
IEEE (Total) & 0 & 3 & 1 & 5 & 6 & 11 & 14 & 19 & 3 & 62 \\
IEEE (Relevant) & 0 & 1 & 0 & 0 & 4 & 2 & 6 & 4 & 0 & 17 \\
IEEE (Selected) & 0 & 0 & 0 & 0 & 1 & 0 & 3 & 1 & 0 & 5 \\
SD (Total) & 1 & 0 & 3 & 6 & 5 & 5 & 16 & 12 & 15 & 63 \\
SD (Relevant) & 1 & 0 & 0 & 2 & 3 & 2 & 4 & 4 & 7 & 23 \\
SD (Selected) & 0 & 0 & 0 & 0 & 0 & 0 & 1 & 2 & 0 & 3 \\
WK (Total) & 0 & 0 & 0 & 0 & 3 & 0 & 3 & 3 & 0 & 9 \\
WK (Relevant) & 0 & 0 & 0 & 0 & 3 & 0 & 2 & 3 & 0 & 8 \\
WK (Selected) & 0 & 0 & 0 & 0 & 2 & 0 & 0 & 2 & 0 & 4 \\
SBGames (Selected) & 0 & 0 & 0 & 0 & 0 & 0 & 0 & 1 & 0 & 1 \\
Excluded papers(duplicated) & $\mathbf{0}$ & $\mathbf{0}$ & $\mathbf{0}$ & $\mathbf{0}$ & $\mathbf{1}$ & $\mathbf{0}$ & $\mathbf{1}$ & $\mathbf{0}$ & $\mathbf{0}$ & $\mathbf{2}$ \\
\hline Total & 4 & 8 & 15 & 29 & 42 & 76 & 84 & 120 & 34 & 413 \\
Total relevant & 1 & 1 & 3 & 4 & 12 & 19 & 20 & 29 & 7 & 96 \\
Total selected & 0 & 0 & 1 & 2 & 2 & 7 & 8 & 17 & 0 & 37 \\
\hline
\end{tabular}

The data of the selected works can be seen in Tab. 3. It can be observed that most of the returned studies is from the field of computer science (about 78\%), which can be explained mainly by the nature of publications from the databases queried. It was also possible to infer that the most used methods were case study and qualitative

Revista Brasileira de Computação Aplicada (ISSN 2176-6649), Passo Fundo, v. 7, n. 1, p. 2-16, abr. 2015 
research based on observations, questionnaires and focus group interviews. Fig. 1 illustrates this categorization of results.

Table 3: Selected papers

\begin{tabular}{|c|c|c|c|c|}
\hline ID & Authors & Year & Methodology used & Research area \\
\hline E1 & Boyle et al.[7] & 2012 & Survey & Psychology \\
\hline E2 & Brown $[8]$ & 2012 & Qualitative research & Computer science \\
\hline E3 & Brox et al.[9] & 2011 & Survey & Medicine \\
\hline E4 & Buiza et al.[10] & 2009 & Case study & Computer science \\
\hline E5 & Carvalho and Ishitani[11] & 2012 & Case study & Computer science \\
\hline E6 & Chen et al.[5] & 2012 & Case study & Education \\
\hline E7 & Foukarakis et al.[12] & 2011 & Prototyping & Computer science \\
\hline E8 & Gajadhar et al.[13] & 2010 & Case study; Qualitative research & Computer science \\
\hline E9 & Gerling et al.[14] & 2012 & Case study & Computer science \\
\hline E10 & Gerling, Schild and Masuch[15] & 2010 & Case study & Computer science \\
\hline E11 & Gerling, Schulte and Masuch[16] & 2011 & Case study & Computer science \\
\hline E12 & Gerling et al.[17] & 2012 & Survey & Computer science \\
\hline E13 & Grosinger, Vetere and Fitzpatrick[18] & 2012 & Prototyping & Computer science \\
\hline E14 & Hori and $\mathrm{Baba}[19]$ & 2010 & Case study & Computer science \\
\hline E15 & IJsselsteijn et al.[20] & 2007 & Survey & Computer science \\
\hline E16 & Kankainen and Lehtinen[21] & 2011 & Qualitative research & Computer science \\
\hline E17 & Kow, Wen and Chen[22] & 2012 & Qualitative research & Computer science \\
\hline E18 & Lim et al.[23] & 2012 & Prototyping & Computer science \\
\hline E19 & López-Martínez et al.[24] & 2011 & Prototyping, Qualitative research & Medicine \\
\hline E20 & Maggiorini, Ripamonti and Scambia[25] & 2012 & Prototyping & Computer science \\
\hline E21 & Mahmud et al.[26] & 2008 & Prototyping & Computer science \\
\hline E22 & Martínez, Morán and Gámez[27] & 2012 & Survey & Computer science \\
\hline E23 & Mubin, Shahid and Mahmud[28] & 2008 & Prototyping & Computer science \\
\hline E24 & Omori and Felinto[29] & 2012 & Case study & Computer science \\
\hline E25 & Palacio et al.[30] & 2012 & Qualitative research & Computer science \\
\hline E26 & Pandeliev and Baecker[31] & 2010 & Prototyping & Computer science \\
\hline E27 & Plaza et al.[32] & 2011 & Survey & Computer science \\
\hline E28 & Portela et al.[33] & 2011 & Qualitative research & Medicine \\
\hline E29 & Rice et al.[34] & 2012 & Qualitative research & Computer science \\
\hline E30 & Rice et al.[35] & 2011 & Case study, Qualitative research & Computer science \\
\hline E31 & Rodriguez et al.[36] & 2012 & Prototyping & Medicine \\
\hline E32 & Schutter and Abeele[3] & 2010 & Qualitative research & Computer science \\
\hline E33 & Shim et al.[37] & 2010 & Prototyping & Computer science \\
\hline E34 & Smith et al.[38] & 2009 & Case study & Psychology \\
\hline E35 & Vasconcelos et al.[4] & 2012 & Case study, Prototyping, Qualitative research & Computer science \\
\hline E36 & Whitlock, McLaughlin and Allaire[39] & 2012 & Qualitative research & Psychology \\
\hline E37 & Yee, Duh and Quek[40] & 2010 & Case study; Qualitative research & Computer science \\
\hline
\end{tabular}

Figure 1: Methods and research area of the selected studies

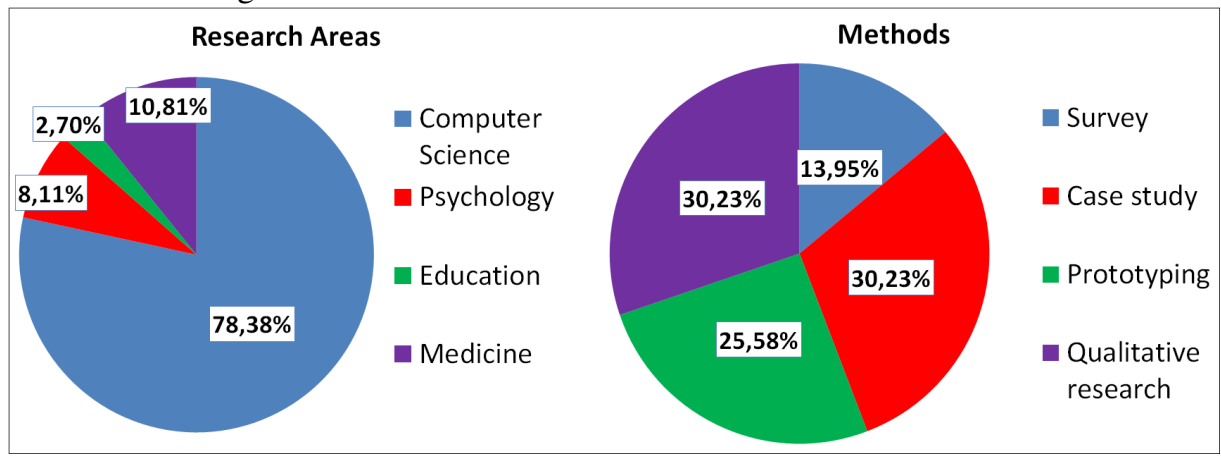

After reading the selected studies, they were categorized according to their adherence to the theme of this work. They were classified with respect to their contribution to answer the research questions defined in Section 
2.1. The results are shown in Fig. 2.

Figure 2: Contribution of studies on the research questions

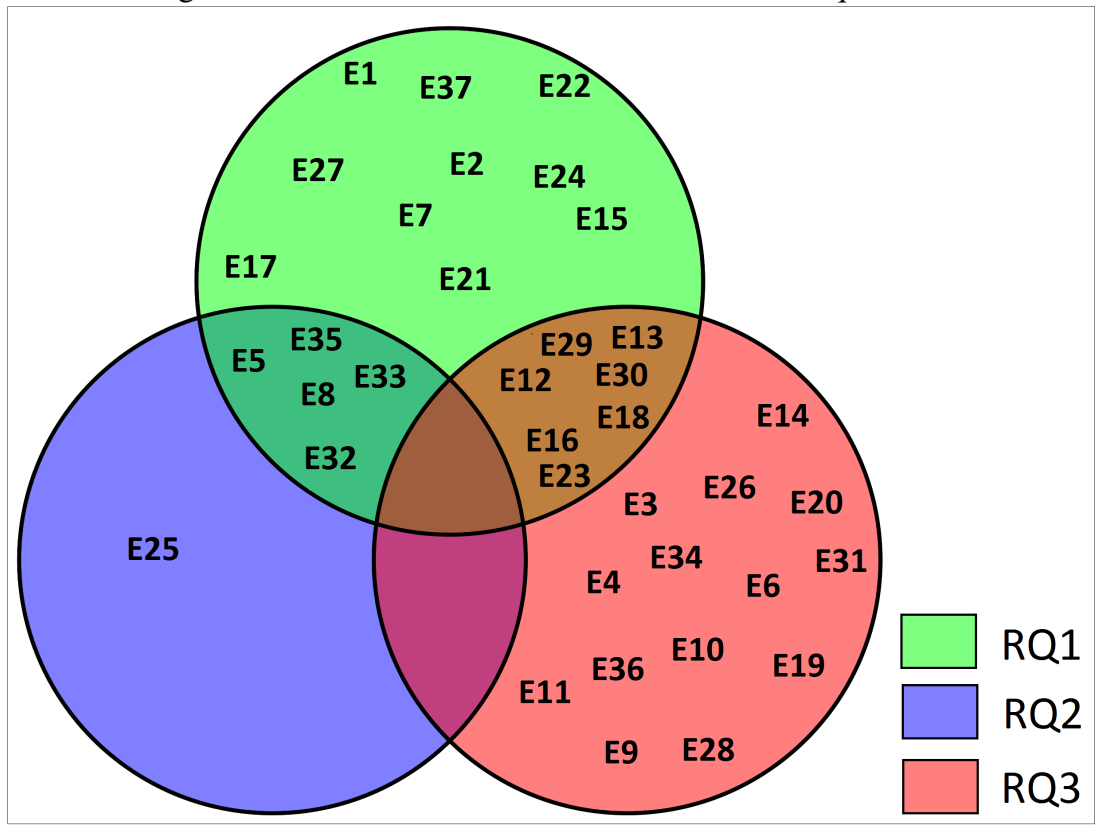

As shown in Fig. 2, the selected papers provided subsidies mainly for research questions 1 and 3. So, there is the need to do more research in the area, in order to answer the RQ2 more properly. 21 papers contributed in some way to answer RQ1 and 22 papers contributed to answer RQ3, which corresponds respectively to $58.3 \%$ and $61.1 \%$ of the analyzed publications. Regarding RQ2, only 6 papers (16.7\%) offered some contribution.

\subsection{Quality assessment of the selected studies}

The studies were qualified in accordance with the quality criteria presented in Section 2.5. The result can be seen in Tab. 4. It can be observed that all studies obtained scores equal to or greater than $50 \%$.

It is important to mention that the low rate in any of the evaluation criteria does not indicate that the study has a low quality as a whole. The indicators used are specific to the purpose of this work and thus a lower percentage only means that the study is not very suitable to the subject of this study.

\section{Discussion}

In this section, we present the contributions of the selected studies to the research questions.

\subsection{RQ1: What are the main factors that motivate the elderly public to become interested in digital games?}

This was the question that the selected papers more addressed (approximately $59 \%$ of the studies). Some studies have pointed out, however, that it is not very clear which are the preferences, motivations and needs of elderly in relation to digital games, which means that there is the need of more research in this area $[8,11,16,20]$.

It was possible to infer that the elderly is attracted by a game generally because of their entertainment 
Table 4: Quality assessment of the selected studies

\begin{tabular}{cccc}
\hline ID & RQ1 & RQ2 & RQ3 \\
E1 & $\mathrm{X}$ & & \\
E2 & $\mathrm{X}$ & & \\
E3 & & & $\mathrm{X}$ \\
E4 & & & $\mathrm{X}$ \\
E5 & $\mathrm{X}$ & $\mathrm{X}$ & \\
E6 & & & $\mathrm{X}$ \\
E7 & $\mathrm{X}$ & & \\
E8 & $\mathrm{X}$ & $\mathrm{X}$ & \\
E9 & & & $\mathrm{X}$ \\
E10 & & & $\mathrm{X}$ \\
E11 & & & $\mathrm{X}$ \\
E12 & $\mathrm{X}$ & & $\mathrm{X}$ \\
E13 & $\mathrm{X}$ & & $\mathrm{X}$ \\
E14 & & & $\mathrm{X}$ \\
E15 & $\mathrm{X}$ & & \\
E16 & $\mathrm{X}$ & & $\mathrm{X}$ \\
E17 & $\mathrm{X}$ & & \\
E18 & $\mathrm{X}$ & & $\mathrm{X}$ \\
E19 & & & $\mathrm{X}$ \\
E20 & & & $\mathrm{X}$ \\
E21 & $\mathrm{X}$ & & \\
E22 & $\mathrm{X}$ & & \\
E23 & $\mathrm{X}$ & & $\mathrm{X}$ \\
E24 & $\mathrm{X}$ & & \\
E25 & & $\mathrm{X}$ & \\
E26 & & & $\mathrm{X}$ \\
E27 & $\mathrm{X}$ & & \\
E28 & & & $\mathrm{X}$ \\
E29 & $\mathrm{X}$ & & $\mathrm{X}$ \\
E30 & $\mathrm{X}$ & & $\mathrm{X}$ \\
E31 & & & $\mathrm{X}$ \\
E32 & $\mathrm{X}$ & $\mathrm{X}$ & \\
E33 & $\mathrm{X}$ & $\mathrm{X}$ & \\
E34 & & & $\mathrm{X}$ \\
E35 & $\mathrm{X}$ & $\mathrm{X}$ & \\
E36 & & & $\mathrm{X}$ \\
E37 & $\mathrm{X}$ & & \\
\hline Total & 22 & 6 & 21 \\
& & &
\end{tabular}

elements, using them mostly as a hobby [7, 21]; however, three studies reported that the elderly are interested in playing games when they see this action as a low cost option to help them maintain their health and to improve their quality of life, as one aid in the treatment of memory and heart problems $[8,17,23]$.

Regarding the technical features of a game that can attract the attention of the elderly, it was possible to detect various aspects considered important. The level of complexity is one. Some studies have indicated that people in this age usually feel more motivated with easy games to play, so they can reach the goal without spending much mental effort $[23,28]$.

Another factor identified as important is the need for feedback on the actions that are happening. Presenting 
to the player what is happening through a progress bar or graphics, for example, contributes to providing him/her a greater control on their actions and consequently greater involvement [23].

The use of elements that fostering social interaction was also cited in several studies. Some reported this feature as a great motivator for the elderly, because the fact of meeting new people or playing against friends makes them feel more engaged and more involved in the activity [3,12, 18, 26, 28, 35, 37]. In this context, we highlight the social games which have as main attractions: the possibility to play with others in asynchronous time; the publishing of activities in social networks; the reward system (unlocking stages, for example); the competition with other players; and the possibility to improve social status, especially after the release of rankings [29]. Intergenerational games also stand out in this subject. They allow grandparents live together with their children or grandchildren of a closer, interactive and enjoyable way, contributing to their learning through educational games, for example [22, 27, 34].

On the other hand, it was also observed that some seniors reported they did not like playing with other people, mainly because of the need to create a schedule with the partner and also the fear of failure when playing against the opponent. One of the studies also indicated that it was not possible to verify the degree of importance of the social element for the elderly, requiring more researches on this topic [13].

Moreover, one of the most important issues to answer this research question is related to the interface, especially its usability and accessibility $[11,12,20]$. The design of screens and player interaction can lead to the success or the failure of a game. As the needs of the elderly are quite varied, creating a single interface that meets all players can become a great challenge. In this context, a good alternative should be to allow the customization of the components of the interface [12].

Therefore, when developing a game project for the old people, it is always necessary to take into account several factors that are not usually considered for younger people, such as reduced visual acuity, reduction in the range of visual accommodation, loss of contrast sensitivity, decreases in dark adaptation, declines in color sensitivity. Therefore, asking to read small subtitles, positioning controls very closely or presenting information scattered across the screen configure inadequate guidelines for these people [20, 23].

Also with respect to the interface, it is recommended that it be intuitive and user friendly in order to improve the player's experience. The use of audible features (like the sound of applauses after actions performed successfully) demonstrated to be a positive option in the design of games for the elderly [23]. The technology also comprises the range of elements that must be taken into consideration. The use of mobile devices for the elderly, for example, should be thoroughly analyzed due to limited resources [32]. Another important factor is how the interaction with the game takes place. Depending on the player's previous experience, he/she may find easier or more difficult to work with touch screen or to use control via gestures, for example [4].

Studies have also informed that the elderly have a preference for games that have narratives: having a plot not just the mechanics of the game itself - makes older people more interested and immersed during the interaction [40]. Another interesting observed issue refers to the insertion of real life scenes in the game. For example, it was noticed a higher performance in memory games with photos of known people to the elderly than with figures from other traditional objects such as fruits, cars or animals [4].

Regarding the negative aspects, in one study, there was unanimity among the elderly when considering the existence of violence in current games as a demotivating factor. They reported that violent games make them remember the days of World War II, bringing them sad memories [4]. Among other demotivating factors pointed out by the elderly, it stands out the action games genre and also games that require the completion of some activity 
against time [3].

\subsection{RQ2: Which genres of digital games the elderly considers most well suited for them?}

This was the question least addressed in the studies surveyed, lacking therefore further research.

A study made an association between the genres of games and the cognitive skills worked on each of them. As a result - despite having identified the need for more research in the area - the following terms were indicated as appropriate for the elderly: patterns, enigmas, find differences, word puzzles, maze and sequence games. It was possible to infer that each modality can stimulate specific cognitive characteristics, such as attention, long-term memory, language comprehension and problem solving [4].

In another study, it was concluded that there is gender differences in preferences. While old women preferred games on gardening, church and walk, old men preferred games related to reading, music and television [30].

Moreover, it can also be noted that the older players have a preference for games that they played when younger. In this context, we highlight the card games, board games and puzzles [4].

Regardless of the game genre, in general, previous work indicated casual game as the type of game most appreciated by the elderly $[3,4,11,13,37]$. This result indicates that the elderly looks for games that suit their lifestyle, without restrictions as time, and without being dependent on the availability of a partner [3, 4, 13].

\subsection{RQ3: Which are the main benefits for the elderly that plays digital games?}

Most of the selected studies detected that digital games can be classified as a major low-cost tool in helping to combat diseases, both in treatment and in prevention. The results showed that games can serve as an aid primarily to treat diseases related to cognitive aspects and those where treatment requires physical activity $[9,17,18,23,31$, 39]. Older people, who may be retired - and thus with more free time - can find in gaming a way to handle leisure activities and fun with health benefits, helping to improve their well-being and to increase their life expectancy $[14,21]$.

The selected papers presented several contributions that the use of games can provide with regard to keeping the health of older people. It was inferred that games can help treat chronic diseases such as diabetes and diseases related to heart problems $[23,36]$. Still in the field of health, it was noted that games can be a good alternative to physical therapy and to stimulate the elderly to adopt the habit of practicing physical activities, through the use interfaces based on movements and gestures control [38, 15, 16, 19, 33, 35]. In addition, there is the advantage that the elderly can perform such activities without leaving the comfort of their homes [25].

The studies reported another positive aspect. Some authors have stated that certain games may reduce the effects related to cognitive difficulties caused by aging, such as loss of memory and lack of attention $[5,10,31]$. The use of some specific games aids in diagnosing and treating neuropsychological diseases, and, in some cases, they may be more efficient than traditional methods for the treatment of psychosocial problems [24].

Another identified benefit is socialization. The results showed that modern technological resources can be used in games so that seniors could meet and relate to others, reducing the effects caused by loneliness and lack of perspective of life in which many find themselves $[3,9,18,24,35]$. Furthermore, the so-called social games can improve the communication with relatives. As an example, one can cite the fact that grandparents feel motivated to

Revista Brasileira de Computação Aplicada (ISSN 2176-6649), Passo Fundo, v. 7, n. 1, p. 2-16, abr. 2015 
play with their children and grandchildren, because in addition to strengthening ties, the game lets intergenerational activity more enjoyable and fun $[22,28,34]$.

\section{Conclusions}

The results presented in this paper allow us to conclude that it is not a simple task to identify what are the factors that instigate the elderly to play. Several resources can contribute to the acceptance of games by this public, such as: low level of difficulty and complexity of the game, the use of narratives, the association with traditional games, the use of elements related to the real-life of players. However, one can notice that there is no certainty as to these factors. Some studies have indicated divergent preferences of the elderly, such as the ability to play with other people, which was considered by some work as an attractive issue and by others as an indifferent or negative factor. In face of it, the best alternative for the game development for elderly may be the possibility of customization, in order to cover a wide range of features and to allow players to choose what is more enjoyable.

It was also possible to infer that casual games are suitable games for the older players. This is justified by the fact that the player does not get too dependent on the game and can perform such activity only in the time they have available. In addition, casual games can be easily played on mobile devices, which are usually more accessible to these people than computers. However, it was found that within this modality there is still a need for more research in order to identify those specific genres that these people appreciate most.

As for the benefits from playing digital games, the selected work presented various notes. Among these, those related to health stand out. Digital games can help improve physical and mental health of players, especially the seniors. Realizing this importance, several areas, such as medicine and psychology, are studying and adopting games as tools in the search for innovative treatments for diseases related to cognitive and physical aspects, among others.

Finally, it is important to note that the issue addressed in this work is recent and therefore still needs more studies to answer the questions raised with greater certainty. As future work, one could expand the research to other devices such as the consoles. In addition, one could verify if the replacement of some terms of the search string, such as "subject" rather than "people", would bring different results.

\section{References}

[1] World Health Organization. Definition of an older or elderly person. Health statistics and health information systems. Disponível em: <http://www.who.int/healthinfo/survey/ageingdefnolder/en/>. Acesso em: 23 ago. 2014.

[2] NAP, H. H.; IJSSELSTEIJN, W. A.; KORT, Y. A. W. Senior Gamers: Preferences, Motivations and Needs. In: Gerontechnology, v. 8, n. 4, 2009. p. 247-262.

[3] SCHUTTER, B. D.; ABEELE, V. V. Designing meaningful play within the psycho-social context of older adults. Proceedings of the 3rd International Conference on Fun and Games, New York, USA: ACM, 2010. p. 84-93.

Revista Brasileira de Computação Aplicada (ISSN 2176-6649), Passo Fundo, v. 7, n. 1, p. 2-16, abr. 2015 
[4] VASCONCELOS, A. et al. Designing tablet-based games for seniors: the example of CogniPlay, a cognitive gaming platform. Proceedings of the 4th International Conference on Fun and Games, New York, USA: ACM, 2012. p. 1-10.

[5] CHEN, T. et al. Effects of improvement on selective attention: Developing appropriate somatosensory video game interventions for institutional-dwelling elderly with disabilities. Turkish Online Journal of Educational Technology, v. 11, n. 4, 2012. p. 409-417.

[6] KITCHENHAM, B. et al. Systematic literature reviews in software engineering - A systematic literature review. Information and Software Technology, v. 51, n. 1, 2009. p. 7-15.

[7] BOYLE, E. A. et al. Review: Engagement in digital entertainment games: A systematic review. Computers in Human Behavior, v. 28, n. 3, 2012. p. 771-780.

[8] BROWN, J. A. Let's play: understanding the role and meaning of digital games in the lives of older adults. Proceedings of the International Conference on the Foundations of Digital Games, New York, USA: ACM, 2012. p. 273-275.

[9] BROX, E. et al. Exergames for elderly: Social exergames to persuade seniors to increase physical activity. Pervasive Computing Technologies for Healthcare (Pervasive Health), 2011 5th International Conference on, 2011. p. 546-549.

[10] BUIZA, C. et al. HERMES: Pervasive Computing and Cognitive Training for Ageing Well. Proceedings of the 10th International Work-Conference on Artificial Neural Networks: Part II: Distributed Computing, Artificial Intelligence, Bioinformatics, Soft Computing, and Ambient Assisted Living, Salamanca, Spain, 2009. p. 756-763.

[11] CARVALHO, R. N. S.; ISHITANI, L. Motivational Factors for Mobile Serious Games for Elderly Users. Proceedings of the 11th SBGames, Brasília, Brazil, 2012. p. 19-28.

[12] FOUKARAKIS, M. et al. An adaptable card game for older users. Proceedings of the 4th International Conference on PErvasive Technologies Related to Assistive Environments, New York, USA: ACM, 2011. p. 27:1-27:7.

[13] GAJADHAR, B. J. et al. Out of sight, out of mind: co-player effects on seniors' player experience. Proceedings of the 3rd International Conference on Fun and Games, New York, USA: ACM, 2010. p. 74-83.

[14] GERLING, K. M. et al. Full-body motion-based game interaction for older adults. Proceedings of the SIGCHI Conference on Human Factors in Computing Systems, New York, USA: ACM, 2012. p. 1873-1882.

[15] GERLING, K. M.; SCHILD, J.; MASUCH, M. Exergame design for elderly users: the case study of SilverBalance. Proceedings of the 7th International Conference on Advances in Computer Entertainment Technology, New York, USA: ACM, 2010. p. 66-69.

[16] GERLING, K. M.; SCHULTE, F. P.; MASUCH, M. Designing and evaluating digital games for frail elderly persons. Proceedings of the 8th International Conference on Advances in Computer Entertainment Technology, New York, USA: ACM, 2011. p. 62:1-62:8.

[17] GERLING, K. M. et al. Game design for older adults: effects of age-related changes on structural elements of digital games. Proceedings of the 11th international conference on Entertainment Computing, Berlin, Germany, 2012. p. 235-242. 
[18] GROSINGER, J.; VETERE, F.; FITZPATRICK, G. Agile life: addressing knowledge and social motivations for active aging. Proceedings of the 24th Australian Computer-Human Interaction Conference, New York, USA: ACM, 2012. p. 162-165.

[19] HORI, Y.; BABA, A. Evaluation of digital games using QOL measurements. Proceedings of the international conference on Multimedia, New York, USA: ACM, 2010. p. 1039-1042.

[20] IJSSELSTEIJN, W. et al. Digital game design for elderly users. Proceedings of the 2007 conference on Future Play, New York, USA: ACM, 2007. p. 17-22.

[21] KANKAINEN, A.; LEHTINEN, V. Creative personal projects of the elderly as active engagements with interactive media technology. Proceedings of the 8th ACM Conference on Creativity and Cognition, New York, USA: ACM, 2011. p. 175-184.

[22] KOW, Y. M.; WEN, J.; CHEN, Y. Designing online games for real-life relationships: examining QQ farm in intergenerational play. Proceedings of the ACM 2012 conference on Computer Supported Cooperative Work, New York, USA: ACM, 2012. p. 613-616.

[23] LIM, J. H. et al. A Closed-Loop Approach for Improving the Wellness of Low-Income Elders at Home Using Game Consoles. Communications Magazine, IEEE, v. 50, n. 1, 2012. p. 44-51.

[24] LÓPEZ-MARTÍNEZ, A. et al. Game of gifts purchase: Computer-based training of executive functions for the elderly. Serious Games and Applications for Health (SeGAH), 2011 IEEE 1st International Conference on, Washington, DC, USA: IEEE Computer Society, 2011. p.1-8.

[25] MAGGIORINI, D.; RIPAMONTI, L.; SCAMBIA, A. Videogame technology to support seniors. Proceedings of the 5th International ICST Conference on Simulation Tools and Techniques, Brussels, Belgium, 2012. p. 270-277.

[26] MAHMUD, A. A. Designing and evaluating the tabletop game experience for senior citizens. Proceedings of the 5th Nordic conference on Human-computer interaction: building bridges, New York, USA: ACM, 2008. p. 403-406.

[27] MARTínEZ A. I. G.; MORÁN, A. L.; GÁMEZ, E. H. C. Towards a taxonomy of factors implicated in children-elderly interaction when using entertainment technology. Proceedings of the 4th Mexican Conference on Human-Computer Interaction, New York, USA: ACM, 2012. p. 51-54.

[28] MUBIN, O.; SHAHID, S.; MAHMUD, A. A. Walk 2 Win: towards designing a mobile game for elderly's social engagement. Proceedings of the 22nd British HCI Group Annual Conference on People and Computers: Culture, Creativity, Interaction, Swinton, UK, v. 2, 2008. p. 11-14.

[29] OMORI, M. T.; FELINTO, A. S. Analysis of motivational elements of social games: a puzzle match 3-games study case. International Journal of Computer Games Technology, 2012.

[30] PALACIO, R. R. et al. Towards videogame design guidelines to promote significant leisure activities in Mexican older adults. Proceedings of the 4th Mexican Conference on Human-Computer Interaction, New York, USA: ACM, 2012. p. 43-46.

[31] PANDELIEV, T.; BAECKER, R. M. A framework for the online evaluation of serious games. Proceedings of the International Academic Conference on the Future of Game Design and Technology, New York, USA: ACM, 2010. p. 239-242. 
[32] PLAZA, I. et al. Mobile applications in an aging society: Status and trends. Journal of Systems and Software, v. 84 , n. 11, 2011. p. 1977-1988.

[33] PORTELA, F. R. et al. Wiitherapy on seniors - Effects on physical and metal domains. Serious Games and Applications for Health (SeGAH), 2011 IEEE 1st International Conference on, Washington, DC, USA: IEEE Computer Society, 2011. p. 1-5.

[34] RICE, M. et al. Co-creating games through intergenerational design workshops. Proceedings of the Designing Interactive Systems Conference, New York, USA: ACM, 2012. p. 368-377.

[35] RICE, M. et al. Evaluating gesture-based games with older adults on a large screen display. Proceedings of the 2011 ACM SIGGRAPH Symposium on Video Games, New York, USA: ACM, 2011. p. 17-24.

[36] RODRIGUEZ, M. D. et al. Persuasive strategies for motivating elders to exercise. Pervasive Computing Technologies for Healthcare (PervasiveHealth), 2012 6th International Conference on, 2012. p. 219-223.

[37] SHIM, N. et al. TableTalk Poker: an online social gaming environment for seniors. Proceedings of the International Academic Conference on the Future of Game Design and Technology, New York, USA: ACM, 2010. p. 98-104.

[38] SMITH, S. T. et al. Electronic Games for Aged Care and Rehabilitation. e-Health Networking, Applications and Services, 2009. Healthcom 2009. 11th International Conference on, Piscataway, NJ, USA: IEEE Press, 2009. p. 42-47.

[39] WHITLOCK, L. A.; MCLAUGHLIN, A. C.; ALLAIRE, J. C. Individual differences in response to cognitive training: Using a multi-modal, attentionally demanding game-based intervention for older adults. Computers in Human Behavior, v. 28, n. 4, 2012. p. 1091-1096.

[40] YEE, S. L. C. Y.; DUH, H. B.; QUEK, F. Investigating narrative in mobile games for seniors. Proceedings of the SIGCHI Conference on Human Factors in Computing Systems, New York, USA: ACM, 2010. p. 669-672.

[41] Entertainment Software Association. Sales, demographic and usage data. Essential facts about the computer and video game industry. Disponível em: <https://www.theesa.com/facts/pdfs/ESA_EF_2013.pdf>. Acesso em: 29 nov. 2014.

[42] Pew Research Center. PewResearch Internet Project. Generations and their gadgets. Disponível em: <http: //www.pewinternet.org/2011/02/03/generations-and-their-gadgets/>. Acesso em: 29 nov. 2014. 